\title{
Varrendo a democracia: considerações sobre as relações políticas entre Jânio Quadros e o Congresso Nacional ${ }^{1}$
}

"Sweeping" democracy: considerations on the political relations between Jânio Quadros and the National Congress

Felipe Pereira Loureiro*

\section{Resumo}

O artigo examina a relação entre o presidente Jânio Quadros e o Congresso Nacional durante o início da década de 1960. Por meio da investigação das ações e dos discursos desses atores, argumenta-se que Jânio manobrou para diminuir a legitimidade política do Congresso diante da opinião pública, desrespeitando as competências constitucionais do Parlamento. Consequentemente, mostra-se que o Congresso não apenas estruturou mecanismos políticos em uma tentativa de reconstruir sua credibilidade diante da sociedade, como também que essa disputa e seus resultados tiveram importantes implicações para o Governo João Goulart e até para o golpe militar de 1964.

Palavras-chave: Jânio Quadros; Congresso Nacional; História política.

\section{Abstract}

This article examines the relation between President Jânio Quadros and the National Congress during the early 1960 's. Based on the analysis of the discourse of these figures, it proposes that Quadros maneuvered to diminish the legitimacy of the Congress in the public opinion, thus disrespecting its constitutional competencies. Consequently, it shows that not only did the Congress structure political mechanisms in an attempt to recover its credibility with society, but also that this dispute and its results had important effects on President João Goulart's administration and even on the 1964 military coup.

Keywords: Jânio Quadros; National Congress (Brazil); Political History.

\footnotetext{
* Doutorando do Programa de História Econômica da FFLCH/USP, Bolsista do CNPq - Av. Francisco de Paula Quintanilha Ribeiro, 280, ap. 114, Bloco I - Vila Campestre. 04330-020 São Paulo - SP - Brasil. fpeloureiro@gmail.com.
} 
Apesar da reconhecida importância do início da década de 1960 para a história brasileira, são escassas as obras que investigaram sistematicamente, do ponto de vista político, a presidência de Jânio Quadros. Quase todos os poucos trabalhos que o fizeram, porém, concentraram a atenção nos fatores da renúncia - sem considerar o momento histórico independentemente desse fato - ou ressaltaram os aspectos pitorescos da atuação janista, tais como seus inúmeros decretos de cunho moralizante. ${ }^{2}$

O estudo das relações entre o presidente Jânio Quadros e o Congresso Nacional, no entanto, é importante não apenas por proporcionar um melhor entendimento da evolução do quadro político-institucional brasileiro do período, mas, também, principalmente, por auxiliar na compreensão dos eventos históricos do Governo João Goulart (tais como a questão das "reformas de base") e que foram, na maioria dos casos, interpretados como associados apenas a esse governo. Até o objeto da renúncia pode ganhar um contorno mais claro mediante a análise das relações entre o Executivo e o Legislativo durante o Governo Quadros.

São de dois tipos as fontes utilizadas neste trabalho: periódicos (O Estado de S. Paulo, SP, e Última Hora, RJ) e publicações oficiais do Legislativo (Diário do Congresso Nacional). Dos primeiros, buscou-se extrair os fatos políticos mais significativos envolvendo os atores em estudo, bem como reunir os pronunciamentos a eles relacionados feitos pelo presidente da República. Por isso, teve-se o cuidado de escolher dois jornais que fossem tanto de circulação nacional, como de tendências ideológicas diferentes. Na publicação do Congresso, visou-se reunir os discursos dos parlamentares, a fim de contrastá-los com os do chefe do Executivo.

No que se refere ao âmbito teórico-metodológico, é preciso salientar um importante aspecto. Na medida em que trabalhamos com discursos, é fundamental assinalar que não se pretendeu aqui tomar a enunciação de determinado ator, seja ele um congressista, seja o próprio presidente, como equivalente necessário às reais intenções dele. Ao contrário, compreende-se o discurso como mais um dos mecanismos utilizados pelos atores no intuito de atingir seus respectivos objetivos políticos (o que não significa, vale ressaltar, que ele tenha apenas essa função). Em outras palavras: a defesa da realização de uma reforma agrária no Brasil pelo presidente Jânio Quadros, em julho de 1961, por exemplo, não necessariamente denota, para nós, que ele tivesse o intuito real de pô-la em prática. Ele pode, ou não, ter buscado esse objetivo. A verificação da veracidade do discurso, apesar de importante, está fora do escopo deste artigo. O que nos interessa são os efeitos que aquela defesa produ- 
ziu na disputa de poder entre o Executivo e o Legislativo federais, bem como a maneira pela qual os parlamentares reagiram a ela.

$\mathrm{O}$ artigo será dividido em três seções: na primeira delas, analisaremos a fase inicial das relações entre Jânio Quadros e o Congresso Nacional, caracterizada por fortes tensões e pela significativa negligência daquele perante os trabalhos deste; na segunda, daremos atenção aos últimos meses da administração janista, quando o presidente aparentou ter mudado seu padrão de relacionamento com os parlamentares; e, por fim, na última seção, apresentaremos as conclusões.

\section{OS PRIMEIROS MESES DO GOVERNO JÂNIO QUADROS}

À primeira vista, Jânio Quadros, eleito presidente da República em outubro de 1960, teria muito trabalho para pôr em prática todas as promessas de moralização administrativa e de reformas socioeconômicas feitas durante a campanha. A configuração partidária do Congresso eleito em 1958 - e que se manteria como tal, salvo alterações marginais, até 1962 - lhe era bastante desfavorável. Os principais partidos da oposição formal ao Governo Jânio PSD (Partido Social Democrático), PTB (Partido Trabalhista Brasileiro) e PSP (Partido Social Progressista) - tinham 64,1\% e 58,6\% das cadeiras na Câmara e no Senado, respectivamente. ${ }^{3}$ Isso obrigava o presidente, caso tivesse interesse efetivo em aprovar suas anunciadas reformas, a procurar uma conciliação com os grupos oposicionistas do Legislativo.

Essa tarefa conciliatória, apesar de todas as dificuldades que a envolviam, abriu-se como possibilidade real antes mesmo de o novo presidente ter assumido o cargo; e o mais importante: sem que a iniciativa viesse do grupo político janista. Benedito Valadares, senador do PSD mineiro, articulou, no início de 1961, a manutenção da aliança entre e PSD e PTB - construída eficazmente durante a administração Kubitschek - , a fim de obter maior capital de barganha junto a Jânio. Em troca de cargos na esfera federal para seus "apadrinhados", Valadares garantiria apoio ao novo presidente em termos de votos no Congresso. Houve, no entanto, forte resistência a essa articulação nos setores progressistas e menos fisiológicos tanto do PTB, quanto do PSD. Por isso, Armando Falcão, aliado de Valadares, chegou a falar na estruturação de um partido centrista, que unisse o chamado campo "adesista" do PSD com a UDN (União Democrática Nacional). A proposta acabou também não obtendo êxito. Além das resistências de setores da UDN a ela, houve outro fator 
determinante para esse insucesso: a falta de interesse demonstrada pelos janistas em levar tal acordo político a cabo. ${ }^{4}$

Dias após as eleições, Jânio anunciou viagem à Europa a fim de, segundo ele, descansar e realizar tratamentos médicos. Seus aliados que permaneceram no Brasil ficaram incumbidos de enviar relatórios sobre a "situação nacional" para que o presidente os estudasse no exterior, e não de articular alianças junto às forças políticas do Congresso. Isolados, sem obterem quaisquer acenos por parte dos janistas de que um acordo junto aos setores da oposição seria bem-vindo, os grupos de Valadares e o dos demais "adesistas" perderam força dentro do PSD perante os aliados de Juscelino Kubitschek, que defendiam uma postura "oposicionista" do partido frente ao novo governo. Teve-se aqui, pela falta de interesse de Jânio em dialogar com o Legislativo, a primeira chance perdida de governabilidade.

As atitudes demonstrativas do descaso de Jânio Quadros quanto à construção de acordos junto às forças políticas majoritárias do Congresso Nacional ficaram mais evidentes a partir da sua posse como presidente da República, em 31 de janeiro de 1961. No mesmo dia em que assumiu o cargo, Jânio proferiu, à noite, no programa de rádio Hora do Brasil, um violento discurso contra o Governo Juscelino. Além de apresentar a "terrível situação financeira do país", criticou a "crise moral, administrativa e político-social" reinante, bem como ressaltou a necessidade de se multiplicarem "órgãos da mecânica democrática, fazendo que surjam, ao lado dos tradicionais, outros, mais próximos das massas". ${ }^{5}$

A reação dos parlamentares oposicionistas, muitos dos quais estavam politicamente vinculados às realizações da última administração, foi imediata. Para além das críticas aos aspectos financeiros do país mencionados na fala presidencial, José Maria Alkmim (PSD-MG) salientou também - tendo em vista as enérgicas promessas punitivas contra supostos "escândalos oficiais" proferidas por Jânio - o tom de "ameaça" ao Congresso presente em tal discurso. De acordo com as próprias palavras do deputado pessedista:

Não estamos neste plenário ... a fim de pedir consentimento de quem quer que seja para cumprir o nosso dever. Nós o cumpriremos, quaisquer que sejam as circunstâncias e não serão essas ameaças veladas, sinuosas ou de entrelinhas que nos hão de amordaçar ou que nos hão de intimidar aqui. ${ }^{6}$

Afora esse aspecto, o deputado Martins Rodrigues (PSD-CE) ressaltou o perigo contido na declaração janista de se criarem órgãos democráticos "mais 
próximos às massas": "Não são esta Casa e o Senado a representação autêntica das massas através do voto? A que novos processos de mecânica democrática ... S. Exa. se refere em sua oração?”.

Alguns parlamentares chegaram a defender Jânio diante dessas acusações (como, por exemplo, Nicolau Tuma, da UDN-SP), mas de modo muito descoordenado. Tal situação era compreensível, pois o governo não havia sequer escolhido ainda um líder no Parlamento, algo interpretado pela imprensa como absolutamente atípico em comparação às administrações anteriores. Apesar da pressão dos líderes da UDN junto ao presidente para que ele chegasse a uma decisão, apenas na semana seguinte Pedroso Horta, ministro da Justiça, convidaria Pedro Aleixo (UDN-MG) e Seixas Dória (UDN-SE) para serem líder e vice-líder do governo, respectivamente. A investidura oficial de Aleixo na liderança, no entanto, só aconteceu quase dois meses depois de sua indicação. Mesmo após isso, foram constantes as reclamações de políticos udenistas quanto à falta de informação sobre os atos do governo. Argumentava-se que, dessa maneira, seria impossível defender a administração janista no Congresso contra ataques dos partidos oposicionistas. Para piorar, em entrevista coletiva concedida no final de maio, Quadros afirmou que não sabia se Aleixo era, de fato, o porta-voz do governo no Parlamento. Vê-se, aqui, que o presidente não apresentou nenhum empenho na construção de uma liderança efetiva no Legislativo; ao contrário, chegou até a minar a já baixa legitimidade de seu suposto líder. ${ }^{7}$

A falta de interesse janista para com o Parlamento não se apresentou apenas nessa questão da liderança, mas também na própria configuração das presidências das casas do Congresso. Sabe-se da importância que os controles das Mesas da Câmara e do Senado possuem para o Executivo Federal. São elas que estabelecem, por exemplo, prioridades de votação para determinados projetos, além de terem condições de trancarem pautas. A colocação de aliados nesses cargos configura, portanto, uma condição fundamental para aprovação de uma agenda do interesse do Executivo.

É de se reconhecer, no entanto, que um presidente que começa o seu mandato sem um líder parlamentar e que realiza um discurso de posse tão enfático contra o governo anterior - tendo em vista a já apresentada composição do Legislativo - não está tão preocupado em angariar apoio para as eleições das Mesas do Congresso. ${ }^{8}$ Isso ficou ainda mais evidente com as atitudes posteriores de Jânio. No segundo dia de trabalho, o presidente iniciou a abertura de sindicâncias a fim de investigar irregularidades em diversos órgãos governamentais durante a administração $\mathrm{JK} .{ }^{9} \mathrm{O}$ fato de o Legislativo não 
ter sido consultado irritou a muitos congressistas, já que, segundo estes, seria possível ao governo averiguar quaisquer irregularidades por meio de Comissões Parlamentares de Inquérito (CPI). Além disso, a presença de militares nas chefias das sindicâncias - muitos dos quais envolvidos com episódios golpistas durante o Governo JK — gerou maiores tensões. ${ }^{10}$

Como forma de se proteger contra as "atitudes autoritárias" do Executivo, parlamentares da oposição, liderados por Abelardo Jurema (PSD-PB), requisitaram, no início de fevereiro, a convocação extraordinária do Congresso. Assim, ao invés de entrar em recesso, o Parlamento continuaria se reunindo pelos próximos 15 dias. Além disso, o deputado Barbosa Lima Sobrinho (PSD-PE) propôs, durante debate na Câmara, a necessidade de se instalarem CPIs paralelas às do Executivo - tese esta aprovada, posteriormente, pelo Diretório Nacional do PSD (OESP, 4 fev. 1961, p.3; 9 fev. 1961, p.3).

A primeira declaração presidencial quanto às articulações do Legislativo contrárias às sindicâncias ratificou ainda mais o descaso de Jânio para com o Congresso: "Que estão pensando? Pois irei aos comícios pedir apoio do povo". Iniciava-se aqui, por meio de declarações referenciadas à "vontade popular", um sistemático processo de deslegitimação do Congresso Nacional feito pelo Executivo perante a opinião pública. A suposta ineficácia parlamentar no que se refere à aprovação de leis era contraposta, por Jânio, à justificável necessidade de o próprio povo falar por si nos momentos em que o presidente não obtivesse sucesso em seus intentos legislativos. Essa abordagem compunha, na realidade, um desenvolvimento da argumentação apresentada no discurso da posse, em que o presidente assinalou a necessidade de se "multiplicarem os órgãos da mecânica democrática”, que já havia irritado a muitos congressistas. A continuidade desse discurso traria duas consequências: em primeiro lugar, um distanciamento cada vez maior entre os poderes Executivo e Legislativo, visível por meio da oportuna utilização, por parte dos congressistas, das atitudes de Jânio como símbolos de um suposto "autoritarismo" presidencial, o qual só poderia ser saneado, segundo os legisladores, mediante o fortalecimento das prerrogativas parlamentares; e, em segundo lugar, pela criação de mecanismos de defesa contra essas atitudes do Executivo por parte do Congresso. A convocação extraordinária do Parlamento durante o recesso de fevereiro de 1961, mantendo-o sob "vigília" - segundo as palavras do presidente do PSD, Amaral Peixoto -, representa uma dessas ações defensivas. ${ }^{11}$

Além disso, nas semanas seguintes, Jânio decretou medidas a fim de facilitar os contatos entre os Executivos Federal, Estadual e Municipal. Com isso, 
tendia-se a esvaziar o papel do Congresso como tradicional mediador entre as demandas regionais e o presidente - o que, por sinal, logo foi percebido pelos parlamentares. O deputado Océlio Medeiros (PSD-PA), por exemplo, chamou os subchefes dos gabinetes civis e militares de "interventores mascarados". Afirmou também que esse decreto seria inconstitucional, pois não estaria regulando uma lei, mas, sim, estabelecendo normas jurídicas novas - prerrogativa essa intransferível, segundo ele, do Congresso Nacional. O deputado Pedro Vidigal (PSD-MG) foi ainda mais enfático contra Jânio, chamando-o de "boi furioso" que "caminha contra a lei". O senador Lima Teixeira (PTB-BA) ressaltou que "o Chefe do Executivo vem dando demonstrações de que quer anular o Congresso, pois, de certo modo, chegou ao ponto de interferir nos Estados...”. Assim, de acordo com o senador, Jânio, com tais medidas, teria prejudicado "a representação política, pois, para trazer ao conhecimento da Nação as ocorrências dos Estados, aqui estão os representantes do povo no Senado da República e na Câmara dos Deputados". Mais uma vez, percebe-se como a oposição lançou mão de argumentos semelhantes ao do episódio do discurso da posse com o intuito de defender e, possivelmente, de fortalecer os poderes do Parlamento. Ao caracterizar Jânio como um magistrado autoritário e que não respeitava as leis, os congressistas usavam instrumentos retóricos semelhantes aos de Quadros para deslegitimar o próprio Poder Executivo. Assim, duas instituições fundamentais da República alimentavam, a cada conflito, a sua própria deslegitimação jurídica.

Com todos esses problemas entre o Executivo e o Legislativo, não é de surpreender que a oposição tenha se mobilizado a fim de comparecer em peso às eleições da Mesa da Câmara e, com isso, obter sua Presidência - o que, de fato, aconteceu. No caso do Senado, diferentemente, como a UDN era a segunda força partidária da Casa, seria natural uma participação situacionista mais forte naquela Mesa. Após intensa disputa entre os candidatos governista (João Vilasboas, UDN-MT) e da oposição (Auro de Moura Andrade, PSD$\mathrm{SP}$ ), este saiu vitorioso, por 30 votos a 27, tornando-se o vice-presidente. Como não houve acordo para que a UDN ficasse com a Primeira Secretaria, o partido decidiu, em ato de protesto, renunciar a todos os demais postos da Mesa senatorial. Com isso, concretizava-se aquilo que a oposição vinha buscando eficazmente desde o início de fevereiro: os principais cargos do Congresso estariam nas mãos do bloco PSD-PTB. Posteriormente, senadores da UDN, tais como João Arruda e Benedito Calazans, proclamaram que a perda do Senado se deveu ao "completo desinteresse" de Jânio pelo Congresso. ${ }^{12}$

É óbvio que, em momento algum, Jânio declarou que articulava um esva- 
ziamento político do Legislativo Federal, tal como a sequência dos seus atos - e a própria percepção e reação dos parlamentares - nos faz concluir. Em entrevista coletiva concedida em abril de 1961, por exemplo, ao ser questionado sobre os termos pelos quais pautava a sua relação com o Congresso, o presidente respondeu:

A Constituição define a minha política, que é de independência e harmonia, no trato com os demais poderes. Ninguém registrou nem registrará da minha parte qualquer ato de hostilidade ou de menosprezo ao Poder Judiciário ou ao Poder Legislativo. Muito ao inverso. Em vários instantes manifestei por esses poderes o acatamento que lhes é devido. Apenas não interfiro neles, porque não posso interferir. (OESP, 15 abr. 1961, p.3)

Em suma: a teoria da independência entre os poderes era a justificativa dada por Jânio para explicar suas atitudes de negligência perante os trabalhos do Congresso. Com isso, ele mantinha, diante da população, a imagem de um representante que não se misturava com os partidos e com os políticos, ao mesmo tempo em que concedia às opiniões mais informadas uma razão legal para as suas atitudes. No fundo, tem-se a impressão de que as constantes e sistemáticas ações janistas de esvaziamento do Congresso se deram para impedir que ele trabalhasse em harmonia com o Executivo, levando, talvez, à necessidade de uma reforma constitucional que fortalecesse a Presidência.

O fato mais emblemático da crise entre o presidente e o Legislativo Federal - e que vem relativizar, portanto, a justificativa de "independência" mencionada antes por aquele para balizar suas atitudes - se refere à famosa "crise da carta”, ocorrida em maio de $1961 .^{13}$ A atitude de Jânio para com João Goulart, vice-presidente da República e, ao mesmo tempo, presidente do Congresso Nacional, foi interpretada pela maioria congressista não apenas como o exemplo máximo de o quanto tais sindicâncias tinham fins políticos, mas também, principalmente, como metáfora da intenção do Executivo de enfraquecer a legitimidade do Legislativo perante a opinião nacional, já que o alvo atingindo, desta vez, tinha sido o próprio presidente dessa instituição.

O líder da Maioria, Pinheiro Chagas (PSD-MG) afirmou, por exemplo, que a atitude de Jânio só reforçava a tendência de incompatibilização entre o presidente e o Congresso, demonstrando que aquele não tinha a intenção de governar, porém, sim, de implantar uma "ditadura no país". ${ }^{14} \mathrm{O}$ deputado Ary Pitombo (PTB-SE) foi tão enfático quanto o prócere pessedista: 
A meu ver, este incidente é apenas um detalhe do esquema do senhor Jânio Quadros para desmoralizar o Congresso Nacional. Essas comissões de inquérito fogem à sua finalidade. Nenhum de nós é contra a apuração de fatos escabrosos, mas o que estamos sentindo e vendo é que as comissões foram constituídas para atingir adversários políticos do Governo ... Mas esteja certo, Sua Excelência, de que este Congresso não se submeterá aos seus arreganhos e estará de pé cumprindo seu dever. Antes cair de pé do que de quatro. O Congresso Nacional manter-se-á de pé frente ao Senhor Jânio Quadros.

San Tiago Dantas (PTB-MG), por sua vez, chamou as sindicâncias de um "Ministério Público de Irresponsabilidade", pois, segundo o deputado trabalhista, apesar de não se configurarem como inquéritos administrativos, elas denunciavam publicamente cidadãos brasileiros sem provas fundamentadas e sem direito de defesa.

Quanto ao episódio da devolução da carta em si, a maioria dos parlamentares se posicionou contrária à atitude presidencial, considerando-a desrespeitosa. Almino Afonso (PTB-AM), por exemplo, afirmou que houve, por parte do presidente, uma "quebra inaceitável de compostura". Além disso, assinalou que as conclusões das sindicâncias não apresentaram claramente nem os crimes que, porventura, Goulart teria cometido, e nem, muito menos, as provas desses atos. Pinheiro Chagas, por sua vez, caracterizou o episódio como um "ato da mais extrema descortesia" e ratificou a solidariedade do PSD para com o vice-presidente.

Os parlamentares da situação, como de costume, mantiveram-se do lado de Jânio. O líder do governo no Congresso, o deputado Pedro Aleixo (UDNMG), proferiu longo discurso de defesa do presidente. Afirmou, entre outros pontos, que Jânio foi desrespeitado primeiro por Goulart, quando este, de modo indevido e descortês, cobrou daquele uma explicação sobre as conclusões das sindicâncias. Sendo ambas figuras as detentoras dos cargos políticos mais importantes do país, Aleixo argumentou que Goulart deveria ter sido mais cauteloso, conversando sobre o assunto com Jânio, ao invés de ter escrito a aquele em tom de cobrança. Além disso, o deputado udenista fez ampla defesa das sindicâncias, considerando que a divulgação das suas investigações - independentemente de serem (ou não) conclusivas quanto aos crimes por elas averiguados - configurava algo "bastante positivo" para a consolidação da democracia e para a retomada da confiança do "homem comum" nas instituições políticas brasileiras. Disse, por fim, que a "falsa honra" é a que queria 
impedir que as verdades fossem conhecidas; o político honesto, segundo ele, não teria o que temer com relação às investigações.

Os argumentos dos parlamentares situacionistas, como não poderiam deixar de ser, foram amplamente rechaçados pelos políticos da oposição. Desta vez, porém, a maioria dos membros do Congresso não permaneceu apenas no plano da retórica. Suas ações contra o que era tachado de "autoritarismo do Executivo" se fizeram sentir de modo mais agudo. Em primeiro lugar, a bancada do PSD, por meio da liderança do deputado Humberto Lucena (PSD-PB), aprovou a tese de que o partido deveria entrar com uma representação contra o presidente da República, nos termos da lei no 1.079 (abril de 1930), por "crime de responsabilidade". Vinte e três atos janistas, tidos como ilegais, na medida em que teriam significado uma "usurpação dos poderes do Legislativo pelo Executivo Federal", estariam na base acusatória. O objetivo do partido era o de, ao longo das investigações, comprovado o "crime de responsabilidade", efetivar o impedimento (impeachment) do presidente da República. Alguns dias depois, a comissão do partido incumbida de apurar os supostos atos irregulares cometidos por Jânio já estava montada. Afora essa iniciativa, outra atitude dos parlamentares merece destaque: a da mobilização em torno da criação de uma CPI para investigar as sindicâncias abertas pelo presidente - mobilização essa adiantada a partir do episódio da carta. Em junho, por exemplo, uma CPI já havia sido instalada para averiguar os procedimentos investigatórios das sindicâncias do SAPS (Serviço de Alimentação da Previdência Social) e dos IAPs (Institutos de Aposentadorias e Pensões). ${ }^{15}$

Aquilo que foi dito na análise de episódios anteriores - tais como o do discurso da posse e o da criação de mecanismos de aproximação entre os Executivos Federal, Estadual e Municipal - vale também para a "crise da carta”. Mesmo que Jânio tivesse boas intenções quanto à investigação de supostas irregularidades na administração pública, a maneira como ele procedeu demonstrou clara falta de interesse do presidente em dialogar com o Congresso e, portanto, em considerá-lo como um ator político legítimo. Os crescentes protestos dos parlamentares da oposição contra tais atitudes representavam forte sinal de que elas estavam suscitando uma crise cada vez mais explícita entre os poderes. Dada a reiteração sistemática desses atos por Jânio e sua repercussão, é possível concluir não apenas que o presidente tinha consciência de tais implicações, como, mais do que isso, que ele tinha interesse em que elas ocorressem.

Os congressistas da oposição, por sua vez, souberam utilizar muito bem o episódio da carta para minar ainda mais a legitimidade de Jânio como pri- 
meiro mandatário. Apesar de o vice-presidente da República também ser, de acordo com a Constituição de 1946, o presidente do Senado, essa competência, mais simbólica do que efetiva, foi exacerbada pelos parlamentares em seus discursos. A superestimação do vínculo de Goulart com o Parlamento, portanto, mostrou-se conveniente naquele contexto, pois ela oferecia aos congressistas mais uma oportunidade para deslegitimar Jânio e, principalmente, para vitimizar o Legislativo diante das “irresponsabilidades" do Executivo.

Um último e, por enquanto, ainda muito obscuro episódio, encerra essa fase de relacionamento mais tenso entre o presidente e o Parlamento: o da greve dos estudantes do Recife. No início de junho de 1961, os estudantes da Universidade de Recife ocuparam o prédio da Faculdade de Direito e a sede da Universidade Rural, além de terem iniciado uma movimentação grevista. O movimento começou quando a Reitoria anunciou que a mãe do revolucionário argentino Ernesto Guevara estaria proibida de discursar em uma conferência ainda a ser realizada no campus. O que deveria ser, no entanto, apenas um ato estudantil se transformou, em razão das atitudes do presidente da República, em uma grave crise institucional. Dias após o início da greve, o governo agiu com força despropositada contra os estudantes, enviando, entre outras, tropas do IV Exército para ocupar os prédios da universidade. Além disso, três unidades navais foram deslocadas para o litoral de Pernambuco, bem como foi mantida uma ponte área entre as principais capitais do país e a cidade de Recife. Afora essas manobras militares, criou-se também um clima de alarme em todo o país. No dia 12 de junho, o presidente da República, após ter declarado que preservaria a "ordem com toda energia" e que continuaria a "defender a autodeterminação do povo cubano", partiu para São Paulo e instalou provisoriamente o seu governo no Palácio do Horto Florestal, na Zona Norte paulistana. Enquanto isso, o ministro da Justiça, Pedroso Horta, ratificava peremptoriamente à imprensa, sem mais explicações, que a "ordem no país seria mantida”. Do Nordeste, chegavam informações de que comunistas, líderes sindicais e vereadores de esquerda - todos sem quaisquer vínculos com a greve estudantil então em curso - estavam sendo presos "por precaução" pelas tropas do Exército. A atmosfera era a de que um golpe iminente estava para acontecer, apesar de poucos conseguirem dizer quem seria seu responsável. ${ }^{16}$

Inúmeros parlamentares salientaram, durante a crise, a delicadeza da situação. O deputado Sérgio Magalhães (PTB-GB), após ter ressaltado que a "intranquilidade era reinante no país", afirmou: 
Há quem diga que S. Exa. [Jânio Quadros] não estaria envolvido no chamado esquema golpista das forças de direita e que, por isso mesmo, já teria abandonado o governo em Brasília para fazê-lo em São Paulo onde possui maiores recursos para sua defensa pessoal. De qualquer maneira, parece inconstitucional a mudança de governo sem que esta Casa tenha sido ouvida ... o que se passa realmente, Sr. Presidente? Há forças golpistas querendo que S. Exa. modifique a sua orientação na política exterior? ${ }^{17}$

Ao final de seu discurso, propôs, sem sucesso, a votação da mudança emergencial da sede do Congresso para São Paulo ou para o Rio de Janeiro. Almino Afonso (PTB-AM), que não se encontrava na Casa, publicou a seguinte nota: "Não se saberá dizer como, nem por quê, nem quando, mas é irrecusável que começa a generalizar-se a apreensão de que as instituições democráticas estão em perigo".

Outros congressistas foram, porém, mais enfáticos em suas críticas a Jânio. Jonas Bahiense (PTB-RJ), por exemplo, salientou o interesse do governo "em não governar", bem como apontou o quanto tais atitudes janistas implicavam sérios riscos para a manutenção das instituições democráticas:

S. Exa. [Jânio Quadros] manda fechar jornais, espancar estudantes, ocupar sindicatos; transfere forças de uma Região Militar para outra de modo acintoso, espetacular; estabelece uma ponte aérea; manda os mais poderosos navios da nossa esquadra para o porto de Recife; e anuncia tudo isso oficialmente através da Hora do Brasil. Pergunto, então, onde estão os propósitos de legalidade e tranquilidade do Governo da República?

Os líderes da situação, por sua vez, tentaram defender novamente o presidente. Afirmaram, por exemplo, que todas as ações janistas citadas se configuravam apenas como "medidas de rotina" e que, portanto, não haveria o clima de golpe no país professado pela oposição. Dessa vez, no entanto, o coro da UDN a Jânio foi menor, já que ninguém sabia de fato o que estava acontecendo.

Além desses discursos apreensivos, o Parlamento também agiu: alguns congressistas foram enviados a Recife com o intuito de estabelecer um acordo entre os estudantes, as tropas do IV Exército e o reitor. Fazia-se necessário, segundo esses parlamentares, acabar com o motivo gerador da crise institucional, que era a própria movimentação estudantil. De qualquer forma, na própria sessão do dia 13 de junho, líderes oposicionistas acertaram a transferência do Congresso para uma dada região do país (mantida, até então, sob 
sigilo), caso se pronunciasse durante sessão no Legislativo uma senha previamente acertada entre eles.

Dias depois, a situação em Recife foi normalizada. Os estudantes acabaram cedendo. Líderes da oposição, como José Maria Alkmim, congratularam os discentes, afirmando que eles haviam percebido que "seu movimento poderia servir de preparação para a ditadura”. Jânio Quadros, instalado no Palácio do Horto Florestal, desmentiu que teriam ocorrido quaisquer ameaças às instituições democráticas durante o episódio. Afirmou, ao contrário, que sua vinda à cidade de São Paulo se deveu exclusivamente a razões médicas, e que não teria, portanto, abandonado a capital como alguns congressistas acusaram. O problema é que, durante sua estada, Jânio não realizou uma única consulta médica sequer. Permaneceu, ao contrário, a semana inteira despachando no Horto, bem como recebendo populares e representantes de entidades sociais diversas. ${ }^{18}$

O episódio da greve dos estudantes de Recife pode ser interpretado como um ataque qualitativamente distinto às instituições por parte de Jânio. Até então, como se tentou mostrar, a ofensiva janista estava sendo dirigida especialmente contra o Congresso Nacional; naquele momento, porém, parece que a própria instituição do Poder Executivo é que estava sendo atacada.

$\mathrm{O}$ visível contraste entre o discurso presidencial antes e depois da crise pode ser interpretado como um forte sinal da intenção de Quadros em desestabilizar as instituições republicanas. Se a estada de Jânio em São Paulo apresentava apenas finalidades médicas, por que o presidente não deixou isso claro desde o início? Por que partiu inesperadamente de Brasília afirmando à imprensa que manteria a "ordem com toda energia", que continuaria defendendo "a autodeterminação de Cuba" e que "ou governaria sem arrepios de autoridade, ou não governaria"? Afora os discursos, lembra-se também que as enfáticas atitudes tomadas pelo governo contrastaram enormemente com as supostas "ameaças à ordem". Por que utilizar forças terrestres e navais extraordinárias para conter simples manifestações estudantis? Por que prender líderes sindicais e vereadores esquerdistas que não tinham relação com os fatos ocorridos e sem que nada de excepcional tivesse acontecido no Nordeste (ao menos que a opinião pública soubesse)? A comparação entre as manifestações presidenciais no início da crise (especialmente no que se refere à autodeterminação de Cuba) e as atitudes que estavam sendo tomadas pelas Forças Armadas contra elementos esquerdistas no Nordeste permite-nos pensar que o presidente tivera a intenção, talvez, de mostrar à sociedade a imagem não apenas de que estava sendo tolhido em suas prerrogativas constitucionais, 
mas também que, diante desse obstáculo, ele se insurgiria por meio da instalação de um governo legítimo em outro local do país (no caso, em São Paulo). Apesar de não existir ainda um estudo específico sobre as relações entre o presidente Quadros e as Forças Armadas, não parece, pelo menos a partir da análise dos periódicos, que Jânio tivesse, naquele contexto, problemas de autoridade no seio do Exército ou da Marinha.

Em suma: se realmente foi Jânio quem ordenou todas as movimentações armamentistas no Nordeste - e, até então, não parece haver indício que apontasse o contrário disso - é possível inferir que o próprio presidente estruturou um verdadeiro teatro de operações a fim de mostrar à sociedade que ele estaria sendo impedido de governar. As atitudes de Jânio, como ele próprio afirmava, em "prol do desenvolvimento da nação", tais como a Política Externa Independente, seriam, supostamente, as responsáveis por essa oposição golpista que poucos sabiam, de fato, de onde provinha. Jânio, ao "resistir" ao golpe, abandonando a capital da República e instalando um governo provisório informal em São Paulo, reforçava a imagem de um político de brio, que não se curvava às supostas forças contrárias ao povo e que arriscava a sua vida para tanto, se assim fosse preciso. À primeira vista, portanto, vê-se que esse episódio constituiu, na realidade, uma espécie de laboratório para a futura renúncia. O presidente tachado sistematicamente de "golpista" pelo Parlamento se colocou, naquele contexto, em posição de quem sofria as consequências de uma manobra ilegal iminente. Pela primeira vez, a vítima não era o Congresso, mas, sim, o próprio Jânio.

Até esse período, observou-se que Quadros ainda possuía, apesar de todos os problemas, o respaldo dos parlamentares da UDN, bem como dos outros partidos que o apoiaram em sua campanha eleitoral (PL e PDC). Pode-se afirmar, assim, que a animosidade dos congressistas para com o presidente não era, até então, generalizada. Essa situação, porém, iria mudar nos meses derradeiros da sua administração.

\section{Os MESES FINAIS Do Governo QuAdros}

O "episódio da carta" foi, mais do que o da própria greve estudantil, um divisor de águas na política de relacionamento do presidente da República com o Congresso Nacional. A partir de junho de 1961, a até então postura de negligência de Jânio com relação ao Legislativo cederia lugar a atitudes mais conciliatórias. É possível que tal alteração de comportamento fosse uma maneira de o presidente defender-se a decisão do Parlamento no sentido de in- 
vestigar as sindicâncias e de processá-lo por "crime de responsabilidade", ou talvez fosse apenas algo que já estava planejado para acontecer independentemente de tais reações. $\mathrm{O}$ fato é que a mudança ocorreu e, mais do que isso, foi percebida pelos atores políticos.

Nessa segunda fase, Jânio iniciou tentativas de aproximação com líderes da maioria oposicionista e radicalizou suas propostas por reformas socioeconômicas. Quanto ao primeiro ponto, ressalta-se a sua mudança brusca de postura com relação ao vice-presidente. Dias após a "crise da carta", Jânio aparentou claramente ter superado o ocorrido, declarando o episódio "encerrado". O presidente autorizou também Pedroso Horta, ministro da Justiça, a aproximar-se de Goulart em seu nome. Durante os diálogos, Jânio garantiu que as sindicâncias não divulgariam mais os resultados das investigações da maneira como vinham fazendo - e, de fato, depois disso, não houve mais divulgações. Além disso, Jânio convidou o vice-presidente, ainda que de modo informal, a chefiar uma missão comercial para a Ásia, que incluiria a China, entre outros países (OESP, 23 maio 1961; 4 jun. 1961, p.3).

Jânio aproximou-se também da bancada do PSD e do PTB, em especial dos deputados Abelardo Jurema e José Maria Alkmim. Em todas as conversas, dizia-se interessado em estabelecer acordos a fim de aprovar as "reformas necessárias para o país”. Além disso, em entrevista coletiva, o presidente afirmou que estava certo de que a UDN isoladamente não representava o pensamento do governo, mas, sim, quem o fazia era "o conjunto dos partidos, em suas diversas afinidades". ${ }^{19}$ Jânio sinalizava favoravelmente, pela primeira vez desde o início de sua administração, ao surgimento de um concerto de forças que apoiasse as políticas encaminhadas pelo Executivo ao Parlamento. "A esta altura", afirmou o presidente na reunião ministerial de julho de 1961, "já se desvaneceram as minhas dúvidas sobre as possibilidades de um governo ser, ao mesmo tempo, democrático e honesto" (OESP, 5 jul. 1961, p.3). Concluise daqui que, antes, Jânio tinha desconfianças quanto à possível conjugação desses dois adjetivos ao sistema político brasileiro. Como a ideologia janista sempre se caracterizou, entre outros aspectos, pela máxima da "honestidade", infere-se que o significante "democrático" era o que estava sendo colocado em xeque pelo presidente. Na reunião ministerial de julho, no entanto, como o próprio Jânio afirmou, essa desconfiança havia acabado, dando a entender que ele encontrava-se aberto para articulações políticas com o Congresso pelas regras democráticas. Isso implicaria não apenas o reconhecimento do Legislativo Federal enquanto um ator político válido, como também a realização de negociações e acordos com os parlamentares. 
O interessante é que, quando perguntado pela imprensa sobre se não estaria desrespeitando a "independência" dos poderes ao agir dessa maneira, Jânio respondeu: "Não sei por que eu esteja ferindo a independência, sobretudo quando, ao lado [dela], há também o dever constitucional: o da harmonia" (OESP, 26 jul. 1961, p.7). É de se questionar, contudo, onde se encontrava o respeito do presidente por esse "dever constitucional" quando, por exemplo, ele deliberadamente deixou de indicar o líder do governo no Congresso no início de sua administração, ou quando não consultou aos parlamentares sobre a possibilidade de investigar irregularidades do Governo JK por meio de CPIs. Vê-se que a contradição entre o discurso e a prática anterior desqualifica a validade do argumento de Jânio relativo à “independência” dos poderes e, da mesma maneira, lança dúvidas quanto à sinceridade do presidente no tocante à nova justificativa apresentada (a da "harmonia").

No que se refere à proposição das reformas socioeconômicas, elas ganharam maior intensidade nos discursos e nas ações presidenciais desde o início de junho de 1961. Alguns exemplos podem ser citados: em uma reunião ministerial nesse mês, o presidente determinou que o ministro das Minas e Energia, João Agripino, coordenasse um grupo de estudos para discutir o conteúdo exato das "reformas de estruturas" necessárias ao país. Nessa mesma reunião, ao pedir determinação aos seus comandados, Jânio chegou até a chorar. Em agosto, o presidente apoiou o projeto de reforma agrária do deputado do PSD José Joffily e declarou à imprensa:

Proclamo aquilo que toda a nação conhece: está caduca a estrutura rural brasileira. A reforma agrária já não é, assim, tema de discurso, mas objeto de ação imediata; ação legislativa e ação executiva ... A primeira etapa é eliminar o latifúndio e condicionar a posse da terra e a monocultura ao interesse social, inclusive para respeitarmos o imperativo constitucional. ${ }^{20}$

No mesmo mês, o presidente enviou ao Congresso um projeto versando sobre a limitação da remessa de lucros ao exterior. ${ }^{21}$ Além disso, a tão anunciada Política Externa Independente (PEI) ganhou corpo. A partir de então, três missões diplomáticas foram enviadas para países socialistas; foram fechados acordos comerciais com nações da Europa do Leste; uma delegação soviética foi recebida no Brasil; e foi reafirmada a defesa da autodeterminação de Cuba.

Entre as consequências dessa mudança do comportamento janista, des- 
taca-se, inicialmente, o surgimento de sérias tensões entre o presidente e os parlamentares conservadores da situação (tais como os da "banda de música" da UDN). Os conservadores, por exemplo, deixaram de defender sistematicamente o governo no Legislativo, em especial quando os temas debatidos se vinculavam à Política Externa Independente ou às "reformas de estrutura". Porém, alguns congressistas da oposição (PSD e PTB) - e até outros da situação, como o grupo da "bossa nova" udenista -, adotaram nesses debates posturas mais favoráveis a Jânio. O fato a se notar, portanto, é o de que tais discussões estavam suscitando a criação no Parlamento de dois grandes segmentos suprapartidários: a Frente Parlamentar Nacionalista (FPN), defensora das "reformas" e que, apesar de ter sido criada oficialmente em 1956, cresceu e se solidificou exatamente nesse contexto; e a Ação Democrática Parlamentar (ADP), anticomunista e antirreformista em sua essência, nascida nesses debates, em junho de $1961 .^{22}$

Apesar dessa relativa aproximação entre Jânio e alguns parlamentares da oposição, muitos congressistas interpretaram a repentina vontade do presidente em dialogar com o Congresso e, sobretudo, em apoiar medidas reformistas, como outra articulação para retirar a legitimidade institucional do Parlamento. De fato, qualquer político sabia das dificuldades de aprovar projetos historicamente polêmicos, tais como o de reforma agrária, ou o de limitação da remessa de lucros. Assim, o eventual fracasso na aprovação desses projetos poderia ser usado, por Jânio, como prova de que a estrutura política brasileira necessitava de alterações. Como, nos discursos do presidente, o binômio "reformas de estrutura" e "superação da crise socioeconômica brasileira" era sempre presente, não seria descabido imaginar que Jânio pudesse ter de fato tal objetivo em mente. A suspeita reforçou-se ainda mais quando um parlamentar bastante ligado a Jânio, o deputado Esmerino Arruda (PSP-CE), propôs um projeto de emenda constitucional que tinha como objetivo a delegação de poderes legislativos ao presidente da República por dezoito meses. Ao Congresso, de acordo com tal projeto, caberia apenas a função de "fiscalizar" os atos do Executivo, e quaisquer irregularidades cometidas por este deveriam ser encaminhadas pelos parlamentares mediante recursos junto ao Supremo Tribunal Federal. ${ }^{23}$

A comoção dos parlamentares em relação ao projeto foi unânime. Pela primeira vez, diferenças político-partidárias ficaram claramente de lado a fim de legitimar o Congresso perante a opinião pública. Os líderes de todas as agremiações políticas, inclusive os da UDN, após longos debates, aprovaram a criação de uma Comissão de Política Parlamentar (CPP). Na justificativa, 
salientava-se que o principal objetivo da comissão seria o de garantir "aos trabalhos parlamentares a maior elevação, eficiência e segurança”. Entre as medidas que seriam tomadas, destacavam-se: evitar que projetos de ordem regimental tramitassem em regime de urgência nas Casas do Congresso (liberando a pauta, dessa maneira, para outros de maior relevância); não enviar, salvo em situações muito específicas, ao plenário os projetos considerados ineptos pelas comissões permanentes; e garantir que o parecer da Comissão de Constituição e Justiça (CCJ) seria definitivo quanto à inconstitucionalidade ou não de projetos - impedindo posterior tramitação quando reprovados (UH, 18 ago. 1961, 1c, p.4).

A renúncia do presidente Jânio Quadros poucos dias depois da criação da CPP apenas teria ratificado, segundo alguns parlamentares, as intenções ditatoriais de Jânio. Não é de surpreender, portanto, que tal ato tenha sido prontamente aceito pelos legisladores, que investiram o sucessor legal de Quadros - Ranieri Mazzilli, presidente da Câmara e terceiro na linha sucessória - rapidamente ao poder.

\section{CONSIDERAÇÕES FINAIS}

O estudo das relações entre o presidente Jânio Quadros e o Congresso Nacional permite-nos agora desenvolver algumas hipóteses. A afirmação de que Jânio teria renunciado com a crença de que o Legislativo exigiria seu retorno à Presidência com mais poderes, tal como alguns autores chegaram a defender, ${ }^{24}$ parece bastante discutível. Viu-se que Jânio atuou, em vários momentos, esvaziando as funções institucionais do Congresso e enfraquecendo a legitimidade deste junto à opinião pública. Mais do que isso: além de simbolizar, para muitos parlamentares, uma ameaça ao regime democrático, Jânio representava também um perigo para as próprias práticas políticas brasileiras, baseadas no clientelismo e no patrimonialismo. Supor, portanto, que Quadros planejava obter o apoio do Congresso Nacional para seu "golpe" apenas pelo fato de que a Vice-Presidência encontrava-se nas mãos de João Goulart, seria interpretar o ato da renúncia isoladamente de toda a história política de sua curta administração. Congressistas de todos os partidos, inclusive os políticos mais conservadores da UDN (tais como seu presidente, Herbert Levy), aceitaram a decisão presidencial e declararam-se favoráveis à posse de Jango.

Um retorno de Jânio ao poder, em novos termos, só seria possível no caso de o Congresso ter sido forçado a tal. O único que teria sido capaz de 
impor tal solução seria o Exército. O flerte de Jânio para com os oficiais associados às malsucedidas tentativas golpistas contra a administração JK; a tentativa de centralização de comando dos Clubes Militares pelo presidente; o episódio da crise dos estudantes de Recife, que envolveu, de fato, uma manobra armada semelhante a um prelúdio golpista; e o ato da renúncia em um momento em que o vice-presidente, temido pelas alas mais conservadoras das Forças Armadas, estava fora do país a mando do próprio Jânio constituem indícios que poderiam apoiar de expectativa de apoio do Exército. Outras atitudes presidenciais, no entanto, vão em outra direção - por exemplo, a questão da Política Externa Independente, que causou discussões e divisões entre os militares. Caso tivesse interesse em usar as Forças Armadas como forma de pressionar o Congresso a aceitá-lo com maiores poderes, por que Jânio arriscaria a unidade de seu plano forçando a defesa de uma política exterior que reconhecidamente provocaria divergências entre os oficiais? Não existe ainda, em nosso modo de ver, uma resposta adequada a essa pergunta. A relação de Jânio com os militares deve, portanto, ser estudada mais detalhadamente para que se possa ter mais elementos para uma avaliação sobre a plausibilidade de tal hipótese.

Afora esse aspecto, alguns dos meios utilizados por Jânio a fim de esvaziar politicamente o Congresso Nacional tiveram importantes consequências na administração posterior. Em primeiro lugar, o constante contraponto feito pelo presidente entre a participação popular direta (via referendo, por exemplo) e a participação popular mediante representação (Legislativo Federal) qualificando a primeira como mais legítima -, garantiriam posteriormente maior base à atuação política dos movimentos da sociedade civil, em especial o dos trabalhadores. Lembre-se que, durante o Governo Goulart, algumas resoluções parlamentares seriam tomadas sob estrita pressão de grupos sociais, tais como, por exemplo, a da antecipação do plebiscito sobre o retorno do presidencialismo.

Em segundo lugar, alguns dos temas levantados por Jânio durante seu embate com os congressistas (como o das famosas "reformas de estrutura") desencadearam forças políticas que o próprio presidente, talvez, não imaginasse. As reformas agrária e bancária, e a política de reatamento de relações comerciais e diplomáticas com países comunistas, levaram a uma divisão político-ideológica suprapartidária que polarizou o Parlamento (ADP e FPN), diminuindo espaços para alianças políticas mais amplas entre os legisladores durante o Governo Goulart. Além disso, a discussão dessa agenda reformista tornou-se mais independente do Executivo a partir da Administração Qua- 
dros. Isso quer dizer que, tivesse sido ou não Goulart o futuro presidente do Brasil após a renúncia de Jânio, a pauta das "reformas de estrutura" já estava posta e dificilmente poderia ser relegada a um segundo plano.

Por último, viu-se que o Parlamento, a fim de se defender das manobras janistas (ou se utilizando dessas manobras para se fortalecer politicamente perante o Executivo), criou mecanismos de agilidade legislativa que foram importantes na aprovação de medidas durante o Governo Goulart, tais como a CPP. Assim, apesar de toda polarização política e ideológica existente no Congresso nesse período (e que, de fato, travou muitas vezes as iniciativas do Parlamento), foram votadas, entre 1961 e 1964, leis como a da Limitação da Remessa de Lucros, a do Antitruste e a do Código Nacional de Telecomunicações.

As evidências apresentadas neste artigo sugerem, portanto, que as relações entre o presidente Jânio e o Congresso Nacional tiveram implicações que ultrapassaram os sete meses da administração janista. Negligenciá-las, ou circunscrevê-las unicamente ao problema da renúncia, significa limitar a compreensão de importantes processos históricos subsequentes, que podem ajudar a esclarecer não apenas as características do Governo Goulart, mas, também, os fatores responsáveis pelo próprio golpe militar de 1964.

\section{NOTAS}

${ }^{1}$ Agradeço a Claudia Simionato, Gustavo Barros, Lidiane Godoi, Renato Colistete e Thomas Kang pela leitura do texto e pelos profícuos comentários e sugestões.

${ }^{2}$ Entre as principais obras que apresentam essa tendência, ver BENEVIDES, M. V. O Governo Jânio Quadros. São Paulo: Brasiliense, 1981; JAGUARIBE, H. A renúncia do presidente Quadros e a crise política brasileira. In: Revista Brasileira de Ciências Sociais, v.1, n.1, nov. 1961, p.272-311; SILVA, H. Os presidentes: Jânio Quadros. São Paulo: Grupo de Comunicação Três, 1983; e VALENTE, N. Jânio Quadros: face a face com a renúncia. São Paulo: Panorama, 1997.

${ }^{3}$ Diário do Congresso Nacional (DCN, 9.mar.1961, 1ª seção, p.1318-1325).

${ }^{4}$ Para mais informações sobre essa articulação de Benedito Valadares, bem como sobre a negligência de Jânio em levar tais diálogos a cabo, ver O Estado de S. Paulo (OESP, 8 jan. 1961, p.3; 10 jan. 1961, p.3) e CASTELLO BRANCO, C. A renúncia de Jânio Quadros. Rio de Janeiro: Revan, 1996. p.70-74.

${ }^{5}$ Para esse discurso de Jânio na íntegra, ver OESP (1 fev. 1961, p.10).

${ }^{6}$ Esse discurso e aquele que será citado a seguir (Martins Rodrigues) podem ser encontrados no DCN (2 fev. 1961, 1' a s., p.602-604).

${ }^{7}$ Sobre o episódio da demorada escolha do líder e do vice-líder do governo no Congresso, 
ver OESP (4 fev. 1961, p.3; 8 fev. 1961, p.3; 2 abr. 1961, p.3). Sobre as reclamações dos líderes udenistas quanto à negligência do governo para com a sua liderança formal no Parlamento, ver OESP (8 jun. 1961, p.3) e Última Hora (UH, 9 jun. 1961, 1º cad., p.4). Para a entrevista de Quadros, ver OESP (31 maio 1961, p.2).

${ }^{8}$ Vale ressaltar que não se pretende, aqui, atribuir juízos de valor ao discurso de posse janista. Pensando-se apenas em termos da estratégia de um presidente recém-empossado, com verdadeiro interesse em construir uma base de apoio no Parlamento, pode-se afirmar que um discurso, tal como o da posse de Jânio, não seria adequado a tais propósitos, tendo em vista a configuração política do Congresso.

${ }^{9}$ Para mais informações, ver VICTOR, M. Cinco anos que abalaram o Brasil: de Jânio Quadros ao Marechal Castelo Branco. Rio de Janeiro: Civilização Brasileira, 1965. p.153-161.

${ }^{10}$ Para discursos de parlamentares da oposição criticando as sindicâncias nos aspectos aqui mencionados, ver, em especial, os pronunciamentos dos deputados Wilson Vargas (PTBRS) e Almino Afonso (PTB-RS), DCN (2 fev. 1961, 1a s., p.605-609; 23 maio 1961, $1^{\text {a }}$ s., p.3430-3433). Para discursos de políticos situacionistas, cuja argumentação se deu no sentido de defender as sindicâncias, vistas como necessárias para a "limpeza da corrupção", ver discurso do deputado Herbert Levy, DCN (23 maio 1961, 1ª s., p.3433-3435).

${ }^{11}$ UH (3 fev. 1961, 1 cad., p.4). Para outros pronunciamentos semelhantes de Jânio, ver UH (9 mar. 1961, 1 cad., p.4). Sobre a convocação extraordinária do Congresso, ver OESP (9 fev. 1961, p.3).

${ }^{12}$ Para a eleição da Mesa da Câmara, ver OESP (4 mar. 1961, p.4 e 11 mar. 1961, p.4); para a do Senado, ver OESP (11 mar. 1961, p.4); e, por fim, para os pronunciamentos dos parlamentares udenistas, ver OESP (12 mar. 1961, p.4).

${ }^{13}$ Em abril de 1961, os relatórios de conclusão das sindicâncias instaladas no SAPS (Serviço de Apoio à Previdência Social) e no IAPB (Instituto de Aposentadoria e Pensões dos Bancários) mencionaram o nome do vice-presidente João Goulart como um dos envolvidos em irregularidades desses órgãos. Após várias tentativas de contato malsucedidas junto aos chefes dessas sindicâncias, Jango enviou uma carta ao presidente da República demandando a retirada do seu nome de tais relatórios, já que, segundo ele, não havia o porquê de o mesmo ali permanecer: não se mencionavam objetivamente no texto nem os crimes que, supostamente, ele teria cometido, e nem, muito menos, as suas respectivas provas. A resposta de Jânio a Goulart, responsável pelo início da crise, foi lacônica e ácida: "Restitua-se a carta ao vice-presidente da República, por não se encontrar vazada em termos próprios, além de não representar a verdade". Para mais informações, ver VICTOR (1965, p.159).

${ }^{14}$ Esse discurso e aqueles que serão citados na sequência (Ary Pitombo, San Tiago Dantas, Almino Afonso, Pedro Aleixo) foram extraídos do DCN (22 maio 1961, $1^{\text {a }}$ s., p.34303435).

${ }^{15}$ Sobre o episódio da abertura do processo de impeachment contra Jânio, ver OESP (19 maio 1961, p.3) e UH (19 maio 1961, $1^{\circ}$ cad., p.4). Para a questão da abertura de CPIs, ver UH (19 maio 1961, $1^{\circ}$ cad., p.4). 
${ }^{16}$ Para os fatos e pronunciamentos citados referentes à greve dos estudantes de Recife, ver OESP (14 jun. 1961, p.2-3) e UH (12 jun. 1961, $1^{\circ}$ cad., p.4; e 14 jun. 1961, $1^{\circ}$ cad., p.4).

${ }^{17}$ Esse discurso e aqueles que serão citados a seguir (Jonas Baiense, Pedro Aleixo) foram extraídos do DCN (13 jun. 1961, 1 cad., p.3983-3985). O pronunciamento de Almino Afonso pode ser encontrado no UH (14 jun. 1961, $1^{\circ}$ cad., p.4).

${ }^{18}$ Para pronunciamento de José Maria Alkmim, ver OESP (17 jun. 1961, p.2 e 4). Para a agenda de Jânio em São Paulo durante o período da crise, ver UH (19 jun. 1961, $1^{\text { cad., }}$ p.4).

${ }^{19}$ OESP (31 maio 1961, p.3). Para reunião com líderes do PSD, ver OESP (6 jul. 1961, p.3) e UH (5 jul. 1961, $1^{\circ}$ cad., p.4). Para encontros com líderes do PTB, ver UH (11 ago. 1961, $1^{\circ}$ cad., p.4). No caso desse partido, Jânio chegou até a convidar um dos seus deputados, San Tiago Dantas (PTB-MG), para ser Chefe da Delegação Permanente do Brasil na Organização das Nações Unidas; UH (10 ago. 1961, 1º cad., p.4).

${ }^{20} \mathrm{UH}$ (3 ago. 1961, $1^{\circ}$ cad., p.4). Para mais informações sobre a reunião ministerial citada, ver OESP (7 jun. 1961, p.3).

${ }^{21} \mathrm{O}$ anteprojeto da lei de remessa de lucros enviado pelo Governo Jânio ao Parlamento, porém, mostrar-se-ia moderado em comparação à lei referente ao tema que seria aprovada pela Câmara dos Deputados no final de 1961.

${ }^{22}$ Para discursos de udenistas contra a postura "pró-reformas de estrutura" do governo, ver, em especial, o pronunciamento do deputado João Mendes na II Convenção da UDN; OESP (2 ago. 1961, p.3). Para a criação da ADP, presidida e articulada pelo próprio João Mendes, ver OESP (9 jun. 1961, p.3).

${ }^{23}$ Sobre a percepção dos parlamentares do PSD e do PTB quanto a essa possível manobra janista de esvaziamento do Congresso, ver OESP (7 jul. 1961, p.3). Para o episódio do projeto de Emenda Constitucional de Esmerino Arruda, ver OESP (13 ago. 1961, p.3) e UH (14 ago. $1961,1^{\circ}$ cad., p.4).

${ }^{24}$ Ver, por exemplo, as afirmações feitas por CHAIA, V. A liderança política de Jânio Quadros (1947-1990). Ibitinga: Humanidades, p.241.

Artigo recebido em outubro de 2008. Aprovado em fevereiro de 2009. 